\title{
Analyzing the Impact of The Psychological Characteristics on Entrepreneurial Intentions Among University Students
}

\author{
Soomro Raheem Bux, Yuan Honglin* \\ School of International Trade and Economics (SITE), Jiangxi University of Finance and Economics, China
}

Copyright (C) 2015 by authors, all rights reserved. Authors agree that this article remains permanently open access under the terms of the Creative Commons Attribution License 4.0 International License

\begin{abstract}
This study aims at assessing the impact of psychological factors on entrepreneurial intentions. For this research, the surveying methodology was used. The sample in this research study contained of 394 students from two universities (Jiangxi University of Finance and Economics and Jiangxi Agriculture University). The participation of respondents in this study was on a voluntary basis. Cronbach's Alpha of the questionnaire was 0.87.The entrepreneurial intention was a dependent variable while innovativeness, locus of control, propensity to take the risk, need for achievement, self-confidence and tolerance to ambiguity were independent variables. Descriptive statistics, independent sample $\mathrm{t}$ test and multiple regressions were employed in order to analyze data through SPSS version 21. Except need for achievement, all other factors showed significant positive impact on entrepreneurial intentions of students. While no difference in entrepreneurial intentions was found between male and female students. And also no difference was found between business students and agriculture students about their intentions for becoming entrepreneurs.
\end{abstract}

Keywords Entrepreneurial Intentions, University Students, Need for Achievement, Propensity to Take the Risk, Entrepreneurship Education, Independent $t$ Test

\section{Introduction}

According to Brandstatter [1] Entrepreneurship has become a public word around the world. Over the last 20 years, "entrepreneurship" has seen tremendous growth, both as a subject of importance in economic policy and correspondingly as a topic of interest for researchers in the social sciences. "Kuratko and Hodgetts [2] said that entrepreneurship has been emerged as the most potent economic force the world has ever experienced". "Schumpeter [3], defined the creation of new ventures is deemed as one of the most important propelling forces for economic development". In a book written by Hisrich, Peters and Shepherd [4], "entrepreneurship has been defined as a process of creating something new with value by devoting the necessary time and effort, assuming the accompanying financial, psychic, and social risk, and receiving the resulting rewards". A reason for this type of significance is that the growth of entrepreneurial activities leads to the creation of various sectors of society. "Mohar, Singh and Kamal [5] said that the developed economies ponder entrepreneurship as an energizing socio economic agent, a way of coping with unemployment problems, a potential catalyst and incubator for technological progress, the product and market innovation. At most of the developing countries, it is seen as an engine of economic progress, job creation and social adjustment". "Levenburg [6] told that the most recent socioeconomic crises like a rapid increase in fuel and food prices, serious threats to social peace and security etc. added to the need of entrepreneurial expansion everywhere in the world particularly at developing countries". "More specifically, Scarborough and Zimmerer [7]; Kuratko and Hodgetts [2] wrote in their books that entrepreneurship is a major engine driving many nations' economic growth, innovation and competitiveness. At the same time, studies of Gorman, Hanlon et al. [8]; Lena and Wong [9]; and Karanassios, Pazarskis et al. [10] have shown there is a positive relationship between entrepreneurship and economic growth in terms of job creation, firm survival and technological change.

"Charney and Libecap [11]; and Hannon [12] said that having exposed to entrepreneurship seems to be a key factor to develop and foster entrepreneurialism. In connection entrepreneurial education can play a vital role. Therefore, "Kuratko [13] said that it is becoming clear that entrepreneurship, or certain facets of it, can be taught". Additionally, in the opinion of Pittaway and Cope [14] "there is some evidence that entrepreneurship education plays a positive role in student entrepreneurial intentions". Furthermore, "Collins and Moore [15] posit how the entrepreneurial role might be culturally and experimentally acquired and therefore influenced by education and training". Entrepreneurial intention has been defined by Bird [16] "as a state of mind which directs and guides the actions of the individual towards the development and implementation of new business concepts". Thus, Sardshmak and Smith [17] 
said that the formation of entrepreneurial intentions is very important to understand entrepreneurial behavior.

On the other hand, there are various psychological characteristics which have significant impact in choosing entrepreneurship (self-employment) as a choice of career. Regarding the psychological features related with intentions of entrepreneurs, a model was presents by "Bygrave [18] that includes: tolerance for ambiguity, internal locus of control, need for achievement and propensity to risk taking". On the other hand, Robinson et al [19], suggest how achievement, control, innovativeness and self-confidence might be good predictors of attitude of entrepreneurs. By focusing on literature, propensity to take risks, locus of control, need for achievement, self-confidence, tolerance to ambiguity and innovativeness are the key psychological features related to entrepreneurship.

The fundamental emphasis of this paper is on the university (undergraduate and graduate) students in order to investigate their entrepreneurial intentions on the basis that younger people are more willing to be self-employed (Blanchflower et al., [20]; Grilo and Irigoyen, [21]". Also, according to Kelley et al [22]. with regard to the age distribution of entrepreneurs, the 24-35 age groups have the highest population for almost every geographic region. Therefore, in terms of developing future potential entrepreneurs, examining university students' entrepreneurial intentions, could have some valuable implications. For this purpose samples have been taken from two universities (Jiangxi University of Finance and Economics and Jiangxi University of Agriculture, China).

There are four parts of this paper. The first part consists on the review of literature and hypotheses for this study. The research methodology employed in this study has been a second part, while the third part furnishes the results and the fourth part provides the summary of the findings, discusses the limitations of the study.

\subsection{Aims of the Study}

1. To ascertain the intentions of students to become an entrepreneur on the base of their psychological characteristics recognized through the literature.

2. To assess the strongest contribution of a character in the entrepreneurial intentions of graduates of both universities.

3. To measure that either change in gender influence entrepreneurial career preferences or not.

4. To assess that either business graduates have higher intentions for choosing Entrepreneurship as a career of their choice than agriculture students or not.

\section{Review of Literature}

\subsection{Entrepreneurial Intentions (EI) and Entrepreneurship}

"Faria, Cuestas \& Mourelle [23] and Parker [24] stated that entrepreneurship is one of the main life-force of modern economic growth, the primary task of which is to influence unemployment". According to Caliendo et al. [25] and Kan and Tsai [26], "Entrepreneurs are generally considered risk-takers and therefore the notion of risk behavior is an important element in the entrepreneurship literature. Miller [27] defined "Risk refers to "unpredictability or possible down side variability of performance" and Simon et al. [28] said the risk-taking propensity of an entrepreneur is high if she is willing to knowingly take risks". Gartner et al. [29] defined an entrepreneur as an "individual who makes a new organization or founds a new venture" and this type of initiative always involves the high rate of risk. "Bygrave and Hofer [30] expanded this definition to someone who perceives an opportunity and creates an organization to pursue it". Rauch \& Frese [31] said that "the most common and practical criterion attached to entrepreneurship is venture creation because establishing, owning, and managing a business are easily identifiable behaviors". And Cunningham \& Lishcheron [32] said that "from the management perspective, entrepreneurs are individuals who organize, own, manage, and assume risk". On the other hand, "Kolvereid [33] said that intention is an indicator of the individual predisposition to act". Intentionality a concept was also defined by "Bird and Jelinek [34] as a state of mind, directing attention, experience, and action toward a specific object (goal) or pathway to its achievements".

\subsection{Need for Achievement}

According to Gurol and Atsan, [35] "Need for achievement is one of the most frequently cited entrepreneurial traits in literature" and "it is the strongest predictor of entrepreneurship (Pillis and Reardon [36]". "According to its traditional definition, Sagie and Elizur, [37] defined the need for achievement is the impetus that forces the person to struggle for success and perfection. "McClelland [38] (1962) said that high achievers take own responsibility, set moderate achievement goals, and take calculated risks and value concrete feedback regarding performance". "Based on the results of his series of studies on the need for achievement, McClelland [39] [40] claimed that such behaviors correlate strongly with entrepreneurial success". "After go through several studies, Johnson [41] found that in spite of the variations in samples studied, operationalizations and measurement of achievement motivation, there is a fairly consistent relationship between achievement motivation and entrepreneurial behavior or inclination". Several comparative studies carried out by Hansemark, [42], Littunen, [43], and Johnson [41] among entrepreneurs and non-entrepreneurs, "it seems that the need for achievement has a more significant relation with entrepreneurship than other characteristics mentioned in the".

\subsection{Locus of Control}

Locus of control (LoC) is one more widely researched trait. 
"Pervin [44] defined locus of control is individual's perception concerning reward and punishment in his life". "Individuals with an external locus of control believe circumstances beyond their immediate control such as luck, fate and other people affect their performance across arrange of activities". Koh, [45], Riipinen [46] and Hansemark [42] said that "Persons with an internal locus of control believe they personally control events and consequences in their lives". It is said that entrepreneurs have an internal locus of control. Empirically, Ho and Koh [47], Robinson et al. [19], Koh [45] and Cromie [48] found that "it is proved that the internal locus of control is one of the major traits of entrepreneurs, and can be a big determinant of success of enterprise. Further, "it was found by Bonnett and Furnham [49] that internal locus of control was found positively associated with the desire to become an entrepreneur".

\subsection{Propensity to Take the Risk}

Propensity to Take the Risk was defined by Kuip and Verheul [50] denotes to "acceptation of risk when engaging in an activity and hence related to the probability of success of any activity being less than 100 percent". However, Erdem [51], Brockhaus [52], Littunen [53] said that "Being in an uncertain environment, entrepreneurship also includes the risks related to financial well-being, career opportunities, family relations, emotional state, and psychic wellbeing". Although, Cromie [48] stated that compared to other groups such as managers, non-entrepreneurs, and teachers, entrepreneurs are found to have higher propensity to take risk. However, according to Cunningham and Lischeron [54], Koh, [45], Thomas and Mueller [55] "study results indicate that entrepreneurs prefer to take moderate risks in their business decisions; they do not like to be involved in situations where there is extreme risk or uncertainty". Therefore, commonsense proposes that entrepreneurs must not be opposed to taking risks.

\subsection{Self-confidence}

Numerous research studies on entrepreneurship have explained self-confidence is an act of risk and therefore high level of self-confidence is essential for this type of act. Therefore, "this characteristic (self-confidence) emerges constantly in a compilation of empirical studies as stated by Davidsson [56]". "Ho and Koh [47] refer that self-confidence is a necessary entrepreneurial characteristic and that it is related to other psychological characteristics, such as the internal locus of control, propensity to take the risk and tolerance of ambiguity". "Robinson et al. [57] have found entrepreneurs to have a higher degree of self-confidence relative to non-entrepreneurs".

\subsection{Tolerance for Ambiguity}

Koh [45] has defined tolerance for ambiguity "when there is insufficient information to structure a situation, an ambiguous situation is said to exist". "Begley and Boyd [58] say that "individuals perceive ambiguity when they lack sufficient clues to structure a situation" and add that while intolerance of ambiguity is defined "as the tendency to perceive ambiguous situations as threatening, tolerance of ambiguity is defined as the tendency to perceive such situations as desirable". Teoh and Foo [59] stated that "If an individual agrees to an insufficient data and trusts his decision taken under uncertainty, his tolerance for such states is considered high". "McMullen and Shepherd [60] link entrepreneurial intent and success with willingness to bear uncertainty". According to Entrialgo et al., [61] "It is commonly believed that entrepreneurial managers tolerate ambiguity better than do conservative managers, because the entrepreneurial ones face a less structured, more uncertain set of possibilities, and actually bear the ultimate responsibility for decision ". "Pillis and Reardon [36] point out that compared to risk propensity, tolerance for ambiguity has been shown to be a better predictor and add that entrepreneurs have been shown to have the higher level of tolerance for ambiguity when compared to managers".

\subsection{Innovativeness}

Innovativeness is a vital component of entrepreneurship. "Schumpeter [62] defined the entrepreneur simply as an innovator". Also, as suggested by Drucker [63], "innovation is the specific tool of entrepreneurs". According to, "Robinson et al. [19] innovativeness is related to perceiving and acting on business activities in new and unique ways". The notion of innovativeness, like other notions, distinguishes entrepreneurs from managers. Gurol and Atsan [35], Koh [45] and Robinson et al. [19] said that empirical research conclusions also backing this notion that "entrepreneurs are more innovative than non-entrepreneurs". "Mueller and Thomas [64] stated that study findings show that innovation is a primary motive of starting a business venture". According to Utsch and Rauch [65]"A number of studies have shown that it also has a significant effect on venture performance".

\subsection{Male and Female Graduates' Entrepreneurial Intentions}

Marlow [66] said that "male versus female entrepreneurship is not just confined to any one gender now rather due to multi-faceted economic pressures women have turned up \& realized that the survival of their families \& their own potential lies only in working side by side with men". Buttner [67] stated that around the globe, "awareness of female entrepreneurship has increased and is characterized by the increasing numbers of women setting up in business". Cooper and Artz [68] found high levels of optimistic expectations regarding their ventures amongst both genders. On similar lines, Minniti et al., [68] found no statistical differences between male and female rates of entrepreneurship were reported in countries like Thailand, China, and South Africa. 


\section{Hypotheses}

H1. There is a positive association between Locus of Control and students' entrepreneurial intentions.

H2. There is a positive association between Propensity to Take the Risk and students' entrepreneurial intentions.

H3. There is a positive association between Self-Confidence and students' entrepreneurial intentions.

H4. There is a positive association between Need for achievement and students' entrepreneurial intentions.

H5. There is a positive association between Tolerance for Ambiguity and students' entrepreneurial intentions.

H6. There is a positive association between Innovativeness and students' entrepreneurial intentions.

H7. Business graduates have more entrepreneurial intentions than Agriculture graduates.

H8. Male graduates have more entrepreneurial intentions than female graduates.

\section{Theoretical Framework}

As a result of the literature review, a research model as illustrated in Figure 01 has been designed. This research model has been used in this research in order to measure the impact of psychological factors (Need for Achievement, Locus of Control, Propensity to Take Risk, Self-Confidence, Tolerance to Ambiguity and Innovativeness) on entrepreneurial intentions of students.

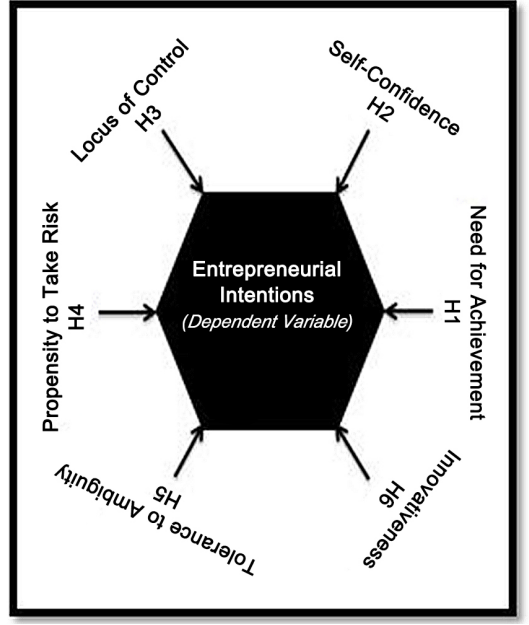

Figure 1. Theoretical Framework

\section{Research Methodology}

\subsection{Sample Description}

Data collection process was completed by a self-administered questionnaire from senior students of Jiangxi University Finance and Economics (senior students of business and economics schools) and Jiangxi Agriculture University (senior students of various agriculture schools). The sample for this study comprised of 450 students from two universities. A number of 450 samples were selected by a random sampling method using Krejcie and Morgan [70] sampling size estimating table. The final sample comprised of $394(87.5 \%)$ respondents after separating questionnaires from several submissions and those survey questionnaires which were incomplete.

\subsection{Questionnaire Description}

In order to complete this study, a self-administered questionnaire was used to get data from respondents linked to this research study topic. To collect data regarding entrepreneurial intentions, items were adopted from Liñán and Chen [71] in order to measure entrepreneurial intentions and the items for studying entrepreneurial characteristics were adopted from Koh [45]. This data collection instrument includes several sections of questions (each section includes 05 to 07 questions) that operationalize the variables about entrepreneurial intentions of students and psychological characteristics. All the questions were framed as sentences replied on Likert Scales of five-point with responses ranging from 1 (Disagree Strongly) to 5 (Agree Strongly). The questions regarding each variable were interspersed a cross the questionnaire to avoid biased responses. A panel of the Chinese $\mathrm{PhD}$ students was requested to translate the questionnaire into a Chinese language. This questionnaire also contained some questions regarding demographic characteristics (age, education and gender) to describe the sample in better way. None of the questionnaires received presented any missing values. In order to measure the internal consistency (reliability) of an instrument, a test of Cronbach's Alpha was used. According to Garson [72] "It measures the extent to which the responses collected for given item correlate highly with each other". According to "Nunnally and Bernstein [73], the reliability score exceeding 0.7 indicates the high internal reliability of a scale items, but there are still researchers like Garson [72], who use different cut-off R-scores like 0.8 or even 0.6 ". The overall internal consistency of all variables of the instrument was higher than the cut-off point of 0.7 (Cronbach's Alpha = 0.87)".

\section{Results}

\subsection{Descriptive Statistics}

Table 01 presents the summary of the respondents' age, gender, marital status and other factors used in this research study. The composition of gender was $53.3 \%$ male $(\mathrm{N}=210)$ and $46.7 \%$ female $(\mathrm{N}=184)$. The composition of marital status was $95.1 \%$ unmarried $(\mathrm{N}=378)$ and 04.9 married. The composition of occupational status was $91.9 \%$ full-time students (362) and part-time students were 29 (07.4). 203 (51.5\%) students participated from JUFE while 191 (48.5\%) students were from JAU. The age composition from 15 to 20 years was37.8\% $(\mathrm{N}=149)$, from 21 to 25 was $60.7 \%(\mathrm{~N}=$ $239)$, while from 26 to 30 was only $1.50 \%(\mathrm{~N}=6)$. 
Table 1. Descriptive Statistics

\begin{tabular}{|c|c|c|c|c|}
\hline Variable & & $\mathrm{N}$ & Mean & $\begin{array}{l}\text { Std. } \\
\text { Dev. }\end{array}$ \\
\hline \multirow{2}{*}{ Gender } & Male & $210(53.3 \%)$ & \multirow{2}{*}{1.47} & \multirow{2}{*}{.500} \\
\hline & Female & $184(46.7 \%)$ & & \\
\hline \multirow{2}{*}{ Marital Status } & Unmarried & $378(95.1 \%)$ & \multirow{2}{*}{1.04} & \multirow{2}{*}{.198} \\
\hline & Married & $16(04.9 \%)$ & & \\
\hline \multirow{2}{*}{ Occupational Status } & Part-time & $32(08.1 \%)$ & \multirow{2}{*}{1.93} & \multirow{2}{*}{.278} \\
\hline & Full-time & $362(91.9 \%)$ & & \\
\hline \multirow{2}{*}{ University } & JUFE & $203(51.5 \%)$ & \multirow{2}{*}{1.48} & \multirow{2}{*}{.278} \\
\hline & JAU & $191(48.5 \%)$ & & \\
\hline \multirow{3}{*}{ Age } & $15-20$ & $149(37.8 \%)$ & \multirow{3}{*}{1.64} & \multirow{3}{*}{.512} \\
\hline & $21-25$ & $239(60.7 \%)$ & & \\
\hline & $26-30$ & $06(01.5 \%)$ & & \\
\hline
\end{tabular}

Table 2. Pearson Correlation

\begin{tabular}{|c|c|c|c|c|c|c|}
\hline Variable & 1 & 2 & 3 & 4 & 5 & 6 \\
\hline 1. Entrep. Int. & 1 & & & & & \\
\hline 2. Loc. of Cont. & $.325^{* *}$ & 1 & & & & \\
\hline 3. Prop. to Cons. & $.381^{* *}$ & $.455^{* *}$ & 1 & & & \\
\hline 4. Self-Confidence & $.238^{* *}$ & $.321^{* *}$ & $.266^{* *}$ & 1 & & \\
\hline 5. Need for Ach. & $.220^{* *}$ & $.388^{* *}$ & $.311^{* *}$ & $.371^{* *}$ & 1 & \\
\hline 6. Tol. for Ambig. & $.225^{* *}$ & $.265^{* *}$ & $.271^{* *}$ & $.365^{* *}$ & $.371^{* *}$ & \\
\hline 7. Innovativeness & $.339^{* *}$ & $.526^{* *}$ & $.435^{* *}$ & $.314^{* *}$ & $.429^{* *}$ & 1 \\
\hline
\end{tabular}

**. Correlation is significant at the 0.01 level (2-tailed)

Sample size $=393$

Table 3. Results of Multiple Regression Analysis

\begin{tabular}{|c|c|c|c|c|c|}
\hline & \multicolumn{2}{|c|}{ Unstandardized Coefficient } & \multirow{2}{*}{$\begin{array}{c}\text { Standardized } \\
\text { Coefficients } \\
\text { Beta } \\
\end{array}$} & \multirow[b]{2}{*}{$\mathrm{t}$} & \multirow[b]{2}{*}{ Sig. } \\
\hline & B & $\begin{array}{l}\text { Std. } \\
\text { Error }\end{array}$ & & & \\
\hline (constant) & -.117 & 1.630 & & -.072 & .943 \\
\hline Locus of Control (LC) & .118 & .069 & .097 & 1.696 & .091 \\
\hline $\begin{array}{l}\text { Propensity to Take Risk } \\
\text { (PR) }\end{array}$ & .356 & .078 & .243 & 4.562 & .000 \\
\hline Self-Confidence (SC) & .134 & .082 & .084 & 1.635 & .103 \\
\hline $\begin{array}{l}\text { Need for Achievement } \\
\text { (NA) }\end{array}$ & -.007 & .076 & -.005 & -.098 & .922 \\
\hline $\begin{array}{l}\text { Tolerance for Ambiguity } \\
\text { (TA) }\end{array}$ & .077 & .070 & .057 & 1.111 & .267 \\
\hline Innovativeness (IN) & .258 & .103 & .145 & 2.513 & .012 \\
\hline
\end{tabular}

Dependent Variable: Entrepreneurial Intentions (EI)

$\mathrm{R}$-square $=.455 \quad$ Adj. $\mathrm{R}$-square $=.207$
$\mathrm{n}=393$

\subsection{Pearson Correlation}

The results of Pearson Correlation are shown in the Table 2. The basic aim of presenting Pearson Correlation estimates is to confirm the relationship between dependent and independent variables. Statistically significant and positive connections between entrepreneurial intentions of students and all other variables have been show in the table 2. Further, the low magnitude of a relationship confirms the absence of multi-collinearity. Whereas, the relationship between entrepreneurial intentions with the Propensity to take Risk is the strongest $(\mathrm{r}=.381, p<0.01)$ among factors. In addition, Innovativeness $(\mathrm{r}=.339, p<0.01)$ and Locus of control $(\mathrm{r}=.325, p<0.01)$ have also a strong relation with entrepreneurial intentions.

\subsection{Regression Results}

The Table 03 presents results of the multiple regression analysis. All dependent and independent variables in the model dimensions were entered simultaneously.

H1 explains that there is a positive association between 
Locus of Control and students' entrepreneurial intentions. The locus of control denotes the level to which individuals trust that their accomplishments are reliant on their own behavior. Therefore, a high level of the locus of control will be tending to take risky undertakings like entrepreneurship. The results here depict significant and positive influence of the locus of control on the students' entrepreneurial intentions $(\beta=.118, p>0.05)$. Based on these results, $H 1$ is supported.

$\boldsymbol{H} \mathbf{2}$ explains that there is a positive association between Propensity to Take the Risk and students' entrepreneurial intentions. This variable denotes to acceptation of risk while becoming the entrepreneur. High level of propensity to take the risk is important to select entrepreneurship as a profession. The findings show the positive significant impact of propensity to take the risk on university students' entrepreneurial intentions of $(\beta=.356, p>0.05)$. According to these results, $H 2$ is approved.

$\boldsymbol{H 3}$ says that there is a positive association between Self-Confidence and students' entrepreneurial intentions. As entrepreneurship is a risky undertaking there high level of self-confidence is required to become an entrepreneur. The results portray the positive significant impact of self-confidence on the entrepreneurial intentions of university students $(\beta=.134, p>0.05$ ). Thus, $H 3$ is supported.

$\boldsymbol{H} 4$ explains that there is a positive association between Need for achievement and students' entrepreneurial intentions. Those people who possess a high degree of need for achievement like to take tolerable risks and have a strong passion for the results of their efforts, they may incline to have high entrepreneurial intentions. Though, the results of this research did not prove hypothesis 4.The influence of the need for achievement on the entrepreneurial intentions of university students was insignificant $(\beta=-.007, p>0.05)$. With this result, $H 4$ stands rejected.

$\boldsymbol{H 5}$ emphasize that there is a positive association between Tolerance for Ambiguity and students' entrepreneurial intentions. Actually, ambiguity is the condition where information is insufficient and therefore high level of tolerance for ambiguity is required to hold entrepreneurial intentions. The result shows the positive impact of tolerance for ambiguity on the students' entrepreneurial intentions $(\beta=.077, p>0.05)$. Based on these result, $H 5$ is supported.

Lastly, $\boldsymbol{H 6}$ propose that there is a positive association between Innovativeness and students' entrepreneurial intentions. Innovativeness is connected to launching and running activities of business in the new and unique way. Because of this, a high level of innovativeness is required to choose an entrepreneurial career. The results explain the positively significant impact of innovativeness on the entrepreneurial intentions of university students $(\beta=.285$, $p>0.05$ ). Therefore, this $H 6$ stands supported.

\subsection{Independent Sample t-tests}

Results of Independent Sample t-tests are given in the Table 04 and 05 . Table 04 furnishes the results for the University. Levene's Test for Equality of Variances test is non-significant because $p=.244$, which is greater than .05 and this means that there is no difference between business students and agriculture students regarding their entrepreneurial intentions. Further, there is no significant difference between intentions of students of JUFE (mean= 14.2936) and students of JAU (mean=15.8532) towards entrepreneurship. Therefore, there is sufficient evidence to reject $H: 07$ and it can now be said that Business graduates have no different entrepreneurial intentions than Agriculture graduates.

The results of Levene's Test for Equality of Variance are shown in Table 4 about Gender. Levene's Test for Equality of Variances test is non-significant owing to $\mathrm{p}=.83$, which is greater than .05 and it means that there is no difference between the entrepreneurial intentions of male and female. Further in both universities, insignificant difference was found between the intentions of male students (mean= 13.9704) and female students (mean $=13.7980)$ towards entrepreneurship. Therefore, there is sufficient evidence to reject $H: 08$ and it can now be said that the entrepreneurial intentions of Male graduates are dissimilar than of Female graduates.

Table 4. Independent Sample t-test for university

\begin{tabular}{|c|c|c|c|c|c|}
\hline & JUFE & JUA & p-value & Decision & Conclusion \\
\hline $\mathbf{N}$ & 193 & 201 & \multirow{4}{*}{0.244} & \multirow{4}{*}{$\begin{array}{l}\text { Fail to } \\
\text { Reject Ho }\end{array}$} & \multirow{4}{*}{$\begin{array}{l}\text { There is insufficient } \\
\text { proof to state that } \\
\text { there is difference in } \\
\text { Entrepreneurial } \\
\text { Intentions by } \\
\text { University (H7) }\end{array}$} \\
\hline Mean & 14.2936 & 15.8532 & & & \\
\hline $\begin{array}{c}\text { Std. } \\
\text { Deviation }\end{array}$ & 4.338 & 4.152 & & & \\
\hline $\begin{array}{c}\text { Std. Error } \\
\text { Mean }\end{array}$ & 0.3122 & 0.2928 & & & \\
\hline
\end{tabular}

Table 5. Independent Sample t-tests for Gender

\begin{tabular}{|c|c|c|c|c|c|}
\hline & Male & Female & p-value & Decision & Conclusion \\
\hline $\mathbf{N}$ & 196 & 198 & \multirow{4}{*}{0.83} & \multirow{4}{*}{$\begin{array}{l}\text { Fail to } \\
\text { Reject Ho }\end{array}$} & \multirow{4}{*}{$\begin{array}{l}\text { There is insufficient } \\
\text { proof to state that } \\
\text { there is difference in } \\
\text { Entrepreneurial } \\
\text { Intentions by } \\
\text { Gender (H8) }\end{array}$} \\
\hline Mean & 13.9704 & 13.7980 & & & \\
\hline $\begin{array}{c}\text { Std. } \\
\text { Deviation }\end{array}$ & 4.1856 & 4.0918 & & & \\
\hline $\begin{array}{l}\text { Std. Error } \\
\text { Mean }\end{array}$ & 0.2997 & 0.2915 & & & \\
\hline
\end{tabular}




\section{Discussion}

The essential aim of this research was to explore the impact of psychological factors on the entrepreneurial intentions of university students. This shows that university students possess high levels of entrepreneurial traits, such as the locus of control, innovativeness, tolerance to ambiguity and need for achievement. The results of this research study are consistent with many previous studies on this topic. "Earlier studies of Neck and Greene [74] and Jusoh et al [75], indicate that these are important features of entrepreneurs and should be incorporated into entrepreneurship education". Although, "several studies like Begley and Boyd [58], Bellu, 1988; Beverland and Lockshin,[76], had identified the need for achievement as a factor vital to the entrepreneurship" but interestingly need for achievement was not found significant in this research. "Studies of Davidsson [56] and Robinson et al.[19] have also suggested a high level of self-confidence as an entrepreneur's standard characteristic and results in this study regarding to self-confidence are consistent with above results". The findings of tolerance for ambiguity in this study are significantly affect entrepreneur intentions, and numerous authors, for example Mitton [77] and Koh [45], consider tolerance to ambiguity as an important entrepreneurial characteristic (e.g. Mitton, 1989; Koh, 1996) and that those who are more entrepreneurial are expected to display more tolerance to ambiguity than others. Locus of control in this study has also shown positive significant impact on entrepreneurial intentions and "research studies of DeVries, [78], Begley and Boyd [58], Beverland and Lockshin [79], Brockhaus [52] and Robinson et al [19], propose the existence of a positive correlation between orientation to the locus of control and entrepreneurship". Almost all current definitions of "entrepreneurship" mention the risk-taking like, Hisrich, Peters and Shepherd [4] define entrepreneurship as "the process of creating something new with value by devoting the necessary time and effort, assuming the accompanying financial, psychic, and social risk, and receiving the resulting rewards". The results of propensity to take a risk in this research study are in alignment with an above definition.

Interestingly, this research did not find any difference between intentions among male and female students and between students of both universities (JUFE and JAU). This may be due to unawareness among students about entrepreneurship. Therefore, it highly required to aware the students about importance of entrepreneurship.

\section{Conclusions}

The results of this cross-sectional study show that university students have high level of entrepreneurial characteristics, such as innovativeness, locus of control, need for achievement and tolerance to ambiguity. Among the selected entrepreneurial traits, propensity to take risk has the highest influence on entrepreneurial intentions. This study shows that students possess entrepreneurial intentions, but there is need to attract their intentions

In order to promote entrepreneurship education among students, various stakeholders (universities, university teachers, media, government, society, commercial banks) have to play their due role in this connection. When planning entrepreneurship education, it should be taken into consideration that students are a heterogeneous group. Therefore, to attract intentions of heterogeneous students through entrepreneurial education, a practical inference is that contents and pedagogical methods of entrepreneurship courses should be tailored in accordance with the intention level of the students and also in the way by which students can be encouraged to become self-motivated and active in the learning process. Through these methods, teachers can target the inspiration of students' motivations for competency development and lead them to become independent thinkers, which according to "Lobler [80] should be a goal to be reached". Ryan and Deci, [81] stated that "Previous studies have shown that autonomy supportive teachers (in contrast to controlling) become catalysts of their students' greater intrinsic motivations, curiosity, and the desire for a challenge". Therefore, the role of teachers has become vital in encouraging an independent thinking among their students inside the classrooms and at their homes. For this purpose, famous local entrepreneurs should be invited by the teachers to deliver lectures and to share their success stories with students inside the classroom. "Izquierdo et al. [82] propose that in- and out- class activities should include the possibility of starting and operating a business while taking entrepreneurship course". For this purpose, universities should create a pool of funds to provide as a financial help to those students who want to test their ideas on a smaller scale during or after taking their entrepreneurship course. Universities should focus on creating research centers for entrepreneurship and establishing business incubation centers (BICs) with the help of local businessmen. In this way close ties can be created between students and local businessmen and these institutes can be extremely fruitful in fostering entrepreneurship among university students.

Further, the media can also play an important role to the promotion of entrepreneurship by publishing and telecasting interviews of successful entrepreneurs.

Government has to play a very key role in promoting entrepreneurship among students by making policies in such ways that students have easy access to the initial capital to launch and run their business. Therefore, governments should make commercial and micro-finance banks responsible to extends loans to newly graduates who want to run their businesses. Further, the legal system should be designed by the governments in a way that more and more protection can be given to newly born businesses.

Owing to the well-recognized significance of entrepreneurship in the society, it is further proposed that entrepreneurship should be taught at least to some degree to all students. In this connection, the universities and higher 
education institutions, in the future, should listen to students and other stake holders when designing syllabuses.

\section{Limitations of this Study}

While interpreting the findings of this study, there are some limitations which should be noted. First, the model in this study has included only certain psychological factors. While certain other factors like personality and environmental factors may be used to measure their impact on entrepreneurial intentions among students. Second, this study is a cross-sectional study in its structure. Further, longitudinal study is also required because intentions may change with a passage of time. Therefore, a longitudinal study should be a good option to measure the actual impacts of influential factors over time. Third, since the study was restricted to academia and owing to sample size, one must be cautious in generalizing the results in other fields.

\section{REFERENCES}

[1] Brandstatter, H. Personality aspects of entrepreneurship: A look of five meta- analyses. Personality and Individuals Differences, (2010). doi: 10.1016/j.paid.2010.07.007.

[2] Kuratko, D. F. and R. M. Hodgetts Entrepreneurship: Theory, Process and Practice. Thomson Learning, Ohio, US, (2004).

[3] Schumpeter, J.A., the Theory of Economic Development, Harvard University Press, Cambridge, MA (1934).

[4] Hisrich, R. D., Peters, M. P. and Shepherd, D. A Entrepreneurship (6th Ed.) McGraw-Hill/Irwin, New York (2005).

[5] Mohar, Y., Singh, M.S. and Kamal, K.K. Relationship between psychological characteristics and entrepreneurial inclination: a case study of students at University Tun Abdul Razak (UNITAR) Journal of Asia Entrepreneurship and Sustainability July 2007, 1-10. (2007).

[6] Levenburg, N.M. Entrepreneurial orientation among the youth of India. Journal of Entrepreneurship. 17(1), 15-35, (2008).

[7] Scarborough, N. M. and T. W. Zimmerer. Effective small business management: An entrepreneurial approach. Upper Saddle River, NJ, Prentice Hall (2003).

[8] Gorman, G., D. Hanlon, et al. "Some research perspectives on entrepreneurship education, enterprise education and education for small business management: A ten-year literature review." International Small Business Journal 15(3): 56-77, (1997).

[9] Lena, L. and P. K. Wong. "Attitude towards entrepreneurship education and new venture creation." Journal of Enterprising Culture 11(4): 339-357, (2003).

[10] Karanassios, N., M. Pazarskis, et al.. "EU strategies to encourage youth entrepreneurship: Evidence from higher education in Greece." Industry \& Higher Education February:
43-50, (2006).

[11] Charney, A. H. and G. D. Libecap. "The contribution of entrepreneurship education: An analysis of the Berger programme." International Journal of Entrepreneurship Education 1(3): 385-418, (2003).

[12] Hannon, P. D. The journey from student to entrepreneur: A review of the existing research into graduate entrepreneurship. UK, National Council for Graduate Entrepreneurship, (2005).

[13] Kuratko, D.F., "The emergence of entrepreneurship education: development, trends and challenges", Entrepreneurship Theory and Practice, Vol. 29 No.5, pp. 577-597, (2005)

[14] Pittaway, L. and Cope, J., "Entrepreneurship education: a systematic review of the evidence", International Small Business Journal, Vol. 25 No.5, pp. 479-510, (2007).

[15] Collins, O.F. and Moore, D.G., the Enterprising Man, Michigan State University Press, East Lansing, MI, (1964).

[16] Bird, B. "Implementing entrepreneurial ideas: The case for intentions", Academy of Management Review, 13, pp. 442-454, (1988).

[17] Sardeshmukh S, Smith R. An examination of skills and abilities in a process model of entrepreneurship (2010), Retrieved 14June 2010, from. http://www.swinburne.edu.au.

[18] Bygrave, W.D., "The entrepreneurship paradigm (I): a philosophical look at its research methodologies", Entrepreneurship: Theory and Practice, Vol. 14, pp. 7-26, (1989).

[19] Robinson, P.B., Stimpson, D.V., Huefner, J.C. and Hunt, H.K., "An attitude approach to the prediction of entrepreneurship", Entrepreneurship: Theory and Practice, Vol. 15 No. 4, pp. 13-31, (1991).

[20] Blanchflower, D.G., Oswald, A. and Stutzer, A., "Latent entrepreneurship across nations", European Economic Review, Vol. 45, pp. 680-91, (2001).

[21] Grilo, I. and Irigoyen, J.M., "Entrepreneurship in the EU: to wish and not to be", Discussion Papers on Entrepreneurship, Growth and Public Policy, Max-Planck Institute, Jena, (2005).

[22] Kelley, D., Bosma, N. and Amoros, J.E., Global Entrepreneurship Monitor 2010 Global Report, Babson College, Universidad del Desarrollo and London Business School, Babson Park, MA, (2010).

[23] Faria J. R., Cuestas J. C. \& Mourelle E. Entrepreneurship and Unemployment: nonlinear bidirectional causality? Discussion papers in economics, No. 2008/6, ISSN 1478-9396, 1-33, 2008.

[24] Parker, S. C. The Economics of Self-Employment and. Cambridge: University Press, (2004).

[25] Caliendo, M., Fossen, F. and Kritikos, A., "Risk attitudes of nascent entrepreneurs-new evidence from an experimentally validated survey", Small Business Economics, Vol. 32 No. 2, pp. 153-167, (2009).

[26] Kan, K. and Tsai, W.D., "Entrepreneurship and risk aversion", Small Business Economics, Vol. 26 No.5, pp. 465 - 474, (2006). 
[27] Miller, K.D. "Risk and rationality in entrepreneurial processes", Strategic Entrepreneurship Journal, Vol. 1 Nos $1 / 2$, pp. $57-74,(2007)$.

[28] Simon, M., Houghton, S.M. and Aquino, K., "Cognitive biases, risk perception, and venture formation: how individuals decide to start companies', Journal of Business Venturing, Vol. 15 No. 2, pp. 113 - 134, (2000).

[29] Gartner, W. B., Shaver, K. G., Gatewood, E., and Katz, J. A. "Finding the Entrepreneur in entrepreneurship (editorial)", Entrepreneurship: Theory \& Practice, (8) 3, pp. 5-9, (1994).

[30] Bygrave, W.D., and Hofer, C.W. "Theorizing about entrepreneurship", Entrepreneurship Theory and Practice, 16, 2, pp.13-22, (1991).

[31] Rauch, A., and Frese, M. "Psychological approaches to entrepreneurial success: A general model and an overview of findings", In C. L. Copper \& I. T. Robertson (Eds.), International Review of Industrial and Organizational Psychology (pp.101-142). Chicester: Wiley, (2000).

[32] Cunnigham, J. B. and Lischeron, J. Defining entrepreneurship. Journal of Small Business Management, 29:45-61, (1991)

[33] Kolvereid, L. Prediction of Employment Status Choice Intentions, Entrepreneurship Theory and Practice, 21(1): 47-57, (1996).

[34] Bird. Implementing entrepreneurial ideas: The case for intentions. Academy of Management Review, 50, 179-211, (1988).

[35] Gürol, Y. and Atsan, N. Entrepreneurial characteristics amongst university students: some insights for entrepreneurship education and training in Turkey. Education + Training, 48(1): 25-38, (2006).

[36] Pillis, E. and Reardon, K. K. The influence of personality traits and persuasive messages on entrepreneurial intention: A cross-cultural comparison. Career Development International, 12(4): 382-396, (2007).

[37] Sagie, A. and Elizur, D., "Achievement motive and entrepreneurial orientation: a structural analysis", Journal of Organizational Behavior, Vol. 20No. 3, pp. 375-87, (1999).

[38] McCelland, D. C. Business drive and national achievement. Harvard Business Review, 40(4):99-112, (1962).

[39] McCelland, D. C. The achieving society. Princeton, NJ: Van Nostrand, (1961).

[40] McCelland, D. C. Achievement motivation can be developed. Harvard Business Review, Nov-Dec:6-24, (1965).

[41] Johnson, B. R. Toward a multidimensional model of entrepreneurship: The case of achievement motivation and the entrepreneur. Entrepreneurship Theory and Practice, Spring: 39-54, (1990).

[42] Hansemark, O.C., "The effects of an entrepreneurship programme on need for achievement and locus of control of reinforcement", International Journal of Entrepreneurial Behaviour \& Research, Vol .4 No.1, pp.28-50, (1998).

[43] Littunen, H., "Entrepreneurship and the characteristics of the entrepreneurial personality", International Journal of Entrepreneurial Behaviour \& Research, Vol. 6 No.6, pp. 295-309, (2000).
[44] Pervin, L.A. Personality: Theory, Assessment and Research, John Wiley \& Sons, New York, NY, (1980).

[45] Koh, H.C., "Testing hypotheses of entrepreneurial characteristics", Journal of Managerial Psychology, Vol. 11No.3, pp.12-25, (1996).

[46] Riipinen, M., "Extrinsic occupational needs and the relationship between need for achievement and locus of control", The Journal of Psychology, Vol. 128 No.5, pp. 577-88, (1994).

[47] Ho, T.S. and Koh, H.C., Differences in psychological characteristics between entrepreneurially inclined and non-entrepreneurially inclined accounting graduates in Singapore", Entrepreneurship, Innovation and Change: An International Journal, 1, pp. 43-54, (1992).

[48] Cromie, S. „Assessing entrepreneurial inclination: Some approaches and empirical evidence", European Journal of Work and Organizational Psychology, 9(1), pp. 7-30, (2000).

[49] Bonnett, C. Furnham, A., Who wants to be an entrepreneur? A study of adolescents interested in a young enterprise scheme", Journal of Economic Psychology, 12(3), pp. 465-478, (1991).

[50] Kuip,I. and Verheul, I., "Early development of entrepreneurial qualities: the role of initial education", EIM Business \& Policy Research, SCALES-paper N200311, Zoetermeer, (2003).

[51] Erdem, F. "A cultural approach toward risk taking propensity and tolerance for ambiguity of entrepreneurs", Akdeniz IIBF Dergisi, Vol. 2, pp. 43-61, (2001).

[52] Brockhaus, R.H., "Risk taking propensity of entrepreneurs", Academy of Management Journal, Vol .23 No.3, pp. 509-20, (1980).

[53] Littunen, H. "Entrepreneurship and the characteristics of the entrepreneurial personality", International Journal of Entrepreneurial Behaviour \& Research, Vol. 6 No.6, pp. 295-309, (2000).

[54] Cunningham, J.B., \& Lischeron, J. "Defining entrepreneurship", Journal of Small Business Management, 29, pp. 45-61, (1991).

[55] Thomas, A.S. and Mueller, S. L. "A case for comparative entrepreneurship: assessing the relevance of culture", Journal of International Business Studies, Vol. 31 No.2, pp. 287-301, (2000).

[56] Davidsson, P. Continued Entrepreneurship and Small Firm Business, Stockholm School of Economics, Stockholm, (1989).

[57] Robinson, P.B., Huefner, J.C., Hunt, H.K., "Entrepreneurial research on student subjects does not generalize to real world entrepreneurs", Journal of Small Business Management, 29, pp. 42-50, (1991).

[58] Begley, T. M. and Boyd, D. Psychological characteristics associated with performance in entrepreneurial firms and small businesses. Journal of Business Venturing, 2:79-93, (1987).

[59] Teoh, H.Y. and Foo, S.L. "Moderating effects of tolerance for ambiguity and risk taking propensity on the role conflict-perceived performance relationship: evidence from Singapore an entrepreneurs", Journal of Business Venturing, Vol. 12, pp. 67-81, (1997). 
[60] McMullen, J. S. and Shepherd, D. A. Entrepreneurial action and the role of uncertainty in the theory of the entrepreneur. Academy of Management Review, 31(1):132-152, (2006).

[61] Entrialgo, M., Fernandez, E. and Vazquez, C., "Characteristics of managers as determinants of entrepreneurial orientation: some Spanish evidence", Enterprise and Innovation Management Studies, Vol. 1 No. 2, pp. 187-205, (2000).

[62] Schumpeter, J., The theory of economic development: An inquiry into profits, capital, credit, interest and the business cycle. In M. Casson (Eds.), Entrepreneurship: 105-134. Hants: Edward Elgar Pub. Ltd, (1990).

[63] Drucker, P. F. Innovation and Entrepreneurship. New York: Harper and Row, Publishers, Inc, (1986).

[64] Mueller, S. L. and Thomas, A. S. Culture and entrepreneurial potential: A nine country study of locus of control and innovativeness. Journal of Business Venturing, 16:51-75, (2000).

[65] Utsch, A. and Rauch, A. Innovativeness and initiative as mediators between achievement orientation and venture performance. European Journal of Work and Organizational Psychology, 9(1):45-62, (2000).

[66] Marlow, s. Women and self-employment; a part of or a part from theoretical construct? International entrepreneurship and management journal., 3(2), 83-91, (2002).

[67] Buttner, E. H. Female entrepreneurs: How far have they come? Business Horizons, 36 (2), 59-65, (1993).

[68] Cooper, A. and Artz, K., "Determinants of satisfaction for entrepreneurs", Journal of Business Venturing, Vol. 10, pp. 439-457, (1995).

[69] Minniti, M., Arenius, P. and Langowitz, N., Global Entrepreneurship Monitor 2004 Report on Women and Entrepreneurship, Babson College, Babson Park, MA, (2005).

[70] Krejice, V. Robert and Morgan W. Daryle. Determining sample size for research activities, Educational and Psychological Measurement. 30,607-610, (1970).

[71] Liña'n, F. and Chen, Y.-W., "Development and cross-cultural application of a specific instrument to measure entrepreneurial intentions", paper presented in a seminar at the European Doctoral Programme in Entrepreneurship and Small Business Management, Universitat Autonoma de Barcelona, Barcelona, (2007).

[72] Garson, D. Guide to writing empirical papers, theses and dissertations. CRC Press, (2002).

[73] Nunnally, J.C., \& Bernstein, I.H. Psychometric Theory. New York: McGraw-Hill, (1994).

[74] Neck, H.M. and Greene, P.G., "Entrepreneurship education: known worlds and new frontiers", Journal of Small Business Management, Vol. 49 No.1, pp. 55-70, (2011).

[75] Jusoh, R., Ziyae, B., Asimiran, S. and Kadir, S.A., "Entrepreneur training needs analysis: implications on the entrepreneurial skills needed for successful entrepreneurs", The International Business \& Economics Research Journal, Vol. 10 No.1, pp. 143-148, (2011).

[76] Bellu, R.R., "Entrepreneurs and managers: are they different?", in Reynolds, P.D., Birley, S., Butler, J.E., Bygrave, W.D., Davidsson, P., Gartner W.B. and McDougall, P.P. (Eds), Frontiers of Entrepreneurship Research, Babson College, MA, pp. 16-30, (1988).

[77] Mitton, D.G., "The complete entrepreneur", Entrepreneurship: Theory and Practice, Vol. 13, pp. 9-19, (1989).

[78] De Vries, K., "The entrepreneurial personality: a person at the cross roads", Journal of Management Studies, Vol. 14 No.1, pp.34-57, (1977).

[79] Beverland, M. and Lockshin, L., "Organizational life cycles in small New Zealand wineries", Journal of Small Business Management, Vol .39 No.4, pp. 354-362, (2001).

[80] Lobler, H.. Learning entrepreneurship from a constructivist perspective. Technology Analysis and Strategic Management, 18, 19-38, (2006).

[81] Ryan, R.M. and Deci, E.L. Intrinsic and extrinsic motivations: Classic definitions and new directions. Contemporary Educational Psychology, 25, 54-67, (2000).

[82] Izquierdo, E. and Buelens, M. Competing models of entrepreneurial intentions: The influence of entrepreneurial self-efficacy and attitudes. International Journal of Entrepreneurship and Small Business, 13, 75-91, (2011). 